\author{
Divya Vakharia* and Suvarna K \\ Gokhale \\ Department of Ophthalmology, Smt. Kashibai \\ Navale Medical College and General Hospital, \\ Maharashtra university of Health Sciences, India \\ Dates: Received: 13 August, 2015; Accepted: 16 \\ September, 2015; Published: 21 September, 2015 \\ *Corresponding author: Dr. Divya Vakharia, \\ Department of Ophthalmology of Smt. Kashibai \\ Navale Medical College and General Hospital, \\ Maharashtra University of Health Sciences, \\ Pune-411041, India. Tel: 919371012884; Fax: \\ +917242437472; E-mail: divya.vakharia@gmail.com \\ www.peertechz.com \\ Keywords: Comparison; Topical; Peribulbar; \\ Phacoemulsification \\ ISSN: 2455-1414
}

\section{Research Article \\ A Comparative Study of Topical Versus Peribulbar Anaesthesia in Phacoemulsification Cataract Surgery and Implantation of Intraocular Lens}

\section{Introduction}

Cataract surgery has become one of the most commonly performed surgical procedures. Newer techniques like small corneal or limbal incisions, phacoemulsification of the lens nucleus $[3,9,21,22]$, and implantation of foldable intraocular lenses [28] have made it possible to switch from general anesthesia to local anesthesia $[12,14,19]$, including retrobulbar or peribulbar injections of local anesthetics. The advent of small, stepped, and self-sealing corneal incisions, in which very little manipulation is required, has allowed the use of Sub-Tenon $[4,15,16,18]$ and topical anesthesia $[5,8,20]$ Peribulbar injection of an aesthetic agents has been used for more than a century in cataract surgery and various modifications have been devised over the last two decades to reduce the risks of injury of intraorbital structures during surgery [17]. The blind insertion of a needle into the retrobulbar space has never been completely free from sight and life threatening complications [17]. Topical anesthesia was first used in 1884 by Koller who used cocaine for topical anesthesia [10]. Topical anesthesia for phacoemulsification was first reported by Kershner in 1993 [20,29]. Innovations in anesthesia, especially topical anesthesia have played an important role in improving outcomes and visual recovery [6]. After one century, Fichman used an attractive alternative method of injecting local an aesthetic agents resulting in faster visual recovery and high patient satisfaction $[10,11]$. The advantages of topical anesthesia include its ease of application, minimal to absent discomfort on administration, rapid onset of anesthesia, rapid visual recovery and more important reduction of risks associated with retrobulbar or peribulbar injection [5]. The technique is also economical, avoids undesirable cosmetic adverse effects, and allows instant visual rehabilitation [5]. The three most common methods of applying topical anesthesia are by eye drops, by eye drops with intracameral lidocaine injection, and in gel form $[1,23]$. Topical anesthesia blocks the trigeminal nerve ending in the cornea and the conjunctiva only [27], leaving the intraocular structures in the anterior segment un-anesthetized. Thus the manipulation of the iris or stretching of ciliary and zonular tissues which may be irritable during surgery in complicated cases could irritate the un anaesthetized ciliary nerve ending and result in patient discomfort and inadvertent eye movement, compromising the overall safety of the procedure [24]. Also the optic nerve and motor neurons are not affected, and the ocular motility is maintained. Topical anesthesia by eye drops is a noninvasive method, but in some cases it may provide insufficient analgesia and require an additional intracameral lidocaine injection [2]. Some reports indicate that topical anesthesia is safe and effective in most uncomplicated cataract procedures. Other studies suggested that topical anesthesia should not be considered in eyes with severe concomitant ocular pathological features. Various studies have 
assessed patient satisfaction with topical versus peribulbar anesthesia with conflicting results $[13,26,30]$. The purpose of the present study was to evaluate the efficacy and safety of topical anesthesia and assess and compare the intra operative complications in phacoemulsification cataract surgery under topical and peribulbar anesthesia.

\section{Materials and Methods}

It is a hospital based prospective comparative randomized study conducted in Smt Kashibai Navale Medical College and General Hospital, Pune (multispecialty hospital) on the senile cataract patients who will be undergoing phacoemulsification cataract surgery under topical and peribulbar anesthesia during the October 2014 to December 2014 in the operation theatre of Ophthalmology in Smt. Kashibai Navale Medical College and General hospital, Narhe, Pune.

\section{Inclusion criteria}

All patients of senile cataract who will be undergoing phacoemulsification cataract surgery with intraocular lens implantation.

1. All diagnosed cases of visually significant senile cataract with reasonable visual potential, who underwent phacoemulsification cataract surgery from October 2014 to December 2014.

2. Patients willing to give written informed consent.

\section{Exclusion criteria}

1. Cases of recurrent uveitis, known previous retinal detachment surgery, corneal opacity, cases of severe external eye diseases (keratoconjunctivitis, blepharitis) and underlying collagen vascular diseases.

2. Patients allergic to xylocaine.

3. Patient with past history of long term local /systemic steroids use as this would affect wound healing.

4. Patients not willing to give written informed consent.

5. Patients with complex anterior segment pathologies.

6. Excessive anxiety, dementia, hearing impairment or poor fixation due to strabismus or nystagmus.

Approval by Institutional Ethics Committee was taken. The patients were given information about all the types of anesthesia to be used in surgery in this study. After their education about the methods of anesthesia, their queries were answered. Well informed written consent was taken and patients were randomly distributed to peribulbar or topical anesthesia. Parameters like age, surgery duration, blood pressure, oxygen saturation and intra-operative pain were compared in two groups to determine the efficacy and safety a particular an aesthetic method out of the two methods being compared. Patients in topical group were treated with proparacaine hydrochloride twice $10 \mathrm{~min}$ before Surgery and just prior to corneal incision. Peribulbar block ( Diffusing agent hyalase was added to the combination of lignocaine hydrochloride and adrenaline, $10 \mathrm{ml}$ of $2 \%$ lignocaine hydrochloride and 1:10000 adrenaline with preadded hyalase) was given ( in peribulbar space $5 \mathrm{ml}$ was injected with $24 \mathrm{G}$ needle at the junction of medial two third and lateral one third; and $5 \mathrm{ml}$ superiorly just medial to supra-orbital notch in the peribulbar space) to other group and breakthrough pain was treated with additional topical anesthetic, which if not effective, was treated with subconjunctival lignocaine. There was stressing effect of peribulbar injection which made patient uncomfortable. After appropriate counseling, the patients were calmed down and the surgery was continued. All the patients were given topical or local anesthesia. So, RAMSAY score could not be used as a standard in this study as it requires a sedated patient and not the patient who is awake and oriented well to time place and person. Surgical procedure was same in both groups. $(2.8 \mathrm{~mm}$ temporal incision was taken and $5.25 \mathrm{~mm}$ diameter posterior chamber intra-ocular lens implant was implanted). The groups did not vary in age, keratometry readings, intraocular pressure, Age related macular degeneration and presence of glaucomatous optic nerve changes. The duration of surgery and intra-operative complications if any were documented. Heart rate, blood pressure, Oxygen saturation (SPO2) was monitored; postoperatively patients were asked to grade the pain during surgery. Ten point scale by Steven was used for that $[0=$ no pain, $10=$ extreme pain], Visual acuity and intraocular pressure were recorded postoperatively. 2-tailed Mann Whitney test for non-parametric statistics and bivariate analysis using chi-square test was done.

\section{Results}

51 patients underwent phacoemulsification under topical anesthesia and 49 patients underwent phacoemulsification under peribulbar anesthesia. No statistical difference was found in surgery duration, intra-operative complications, pain, blood pressure or Oxygen saturation (SPO2). Topical group did not require additional subconjunctival injection. $4 / 49(8.16 \%)$ in peribulbar group required additional topical anesthesia. This was statistically significant $(\mathrm{p}=0.04)$. No patient was lost due to anesthetic or any other complications. Anesthesia related complications were only seen in peribulbar group which included chemosis, ecchymosis, subconjunctival hemorrhage and peribulbar hemorrhage. Table 1 shows comparison and the statistical significance of the parameters assessed (number of patients-n, age, pain score, blood pressure

\begin{tabular}{|l|c|c|c|}
\hline \multicolumn{3}{|l|}{ Table 1: } & \multicolumn{3}{l|}{ TOPICAL } & PERIBULBAR & p-value \\
\hline $\mathrm{n}$ & 51 & 49 & \\
\hline age & 73.21 & 73.57 & 0.71 \\
\hline Pain score & 1.49 & 1.48 & 1 \\
\hline Systolic Blood pressure at start of surgery & 154.90 & 154.44 & 0.0016 \\
\hline $\begin{array}{l}\text { Diastolic Blood pressure at start of } \\
\text { surgery }\end{array}$ & 79.56 & 79.95 & 0.17 \\
\hline $\begin{array}{l}\text { Systolic Blood pressure at the end of } \\
\text { surgery }\end{array}$ & 155.58 & 154.97 & 0.061 \\
\hline $\begin{array}{l}\text { Diastolic Blood pressure at the end of } \\
\text { surgery }\end{array}$ & 79.76 & 79.53 & 0.27 \\
\hline SPO2 & 98.47 & 98.46 & 0.99 \\
\hline Intra-ocular pressure & 16.79 & 16.72 & 0.91 \\
\hline Duration of surgery & 15.19 & 15.63 & 0.43 \\
\hline
\end{tabular}




\section{Table 2:}

Davis \& Mandal 1994a; (Fukasaku \&

Marron 1994; Tseng \& Chen 1998; Koch In our study. 1999).

Indicated that iris manipulation and stretching of uveal tissue irritates patients in topical group.

at start and end of surgery, oxygen saturation-SPO2, intraocular pressure and duration of surgery).

\section{Discussion}

The complications of peribulbar and retrobulbar anesthesia led to the search for other alternatives. Fichman in 1996 proposed topical anesthesia. It causes faster visual recovery, higher patient satisfaction, easy to administer, minimal/no discomfort on instilling, rapid onset, is economic, no cosmetic side effects. Also confirming with previous studies (Jacobi et.al. 2000), it is safe and effective. It being non-invasive, does requires less intra and post-operative monitoring compared to peribulbar anesthesia which makes it cost-effective. It allows full ocular motility which is helpful in relative enophthalmos and prominent orbital rims. Visual rehabilitation is also better and faster as extra ocular movements and Optic nerve are not partially blocked by anesthetics. Topical anesthesia is useful in patients with previous retinal detachment surgery and Sclera buckling have scar which limits diffusion of peribulbar anesthetics. Highly axially myopic patients are at increased risk of globe perforation. They need to be operated under GA unless topical anesthesia is available. In our study peribulbar anesthesia related complications did not prevent or delay any planned surgical intervention. In this study topical group required anesthesia less frequently than peribulbar group and Effectiveness of anesthesia is estimated by frequency of additional steps required to achieve pain free surgery. Table 2 shows the comparison of present study with previous study.

\section{Conclusion}

From this, we can conclude that the cataract surgery can be performed with topical anesthesia without compromising safety of procedure and definitely a beneficial procedure.

\section{Acknowledgement}

Dr. Divya Vakharia, Dr. Suvarna K. Gokhale and funding was not required so grant details are not there.

\section{References}

1. Bardocci A, Lofoco G, Perdicaro S, Ciucci F, Manna L (2003) "Lidocaine $2 \%$ gel versus lidocaine $4 \%$ unpreserved drops for topical anesthesia in cataract surgery: a randomized controlled trial. Ophthalmology 110: 144-149.

2. Crandall AS, Zabriskie NA, Patel BC, Burns TA, Mamalis N, et al. (1999) A comparison of patient comfort during cataract surgery with topical anesthesia versus topical anesthesia and intracameral lidocaine. Ophthalmology 106 : 60-66.

3. Boyd BF (1975-1976) Personal interview between the editor and RC Troutman, D Paton, S Ryan. Present trends in incision closure of the cataract wound. Highlights Ophthalmol 14: 176-204.

4. Canavan KS, Dark A, Garrioch MA (2003) Sub-Tenon's administration of local anaesthetic: a review of the technique. $\mathrm{Br} \mathrm{J}$ Anaesth 90: 787-793.

5. Claoue C, Lanigan C (1997) Topical anesthesia for cataract surgery. Aust N Z J Ophthalmol 25: 265-268.

6. Colvard DM, Kandavel R (2009) Achieving excellence in cataract surgery; A step by step approach. Springer

7. Crandall AS (2001) Anesthesia modalities for cataract surgery. Curr Opin Ophthalmol 12: 9-11.

8. Ezra DG, Allan BD (2007) Topical anaesthesia alone versus topical anaesthesia with intracameral lidocaine for phacoemulsification. Cochrane Database Syst Rev CD005276.

9. Fichman RA (1993) The clear-corneal incision and astigmatism strategies. In: Fine IH, Fichman RA, Grabow HB, (eds), Clear-Corneal Cataract Surgery and Topical Anesthesia. Slack, Thorofare, NJ: 72-76.

10. Fichman RA (1992) Topical eye drops replace injection for anesthesia. Ocular Surgery News 1: 20-21.

11. Fichman RA (2001) Topical technique appear safer in patient with anticoagulant Anesthesia. Intensive Care 29: 8-11.

12. FICHMAN RA (2001) Use of topical anesthesia alone in cataract surgery. J Cataract Refract Surg 22: 612- 614.

13. Sauder G, Jonas JB (2003) Topical versus peribulbar anesthesia for cataract surgery. Acta Ophthalmol Scand 81: 596-599.

14. Gills JP, Cherchio M, Raanan MG (1997) Unpreserved lidocaine to control discomfort during cataract surgery using topical anesthesia. J Cataract Refract Surg 23: 545-550.

15. Gray R, Lucas J (2002) “No needle” sub-Tenon's anesthesia. Br J Ophthalmol 86: 831.

16. Greenbaum S (1997) Anesthesia in cataract Surgery. In: Greenbaum S (ed), Ocular Anesthesia. Saunders, Philadelphia, PA: 1-55

17. Hamilton RC (1985) Brain stem anesthesia following retro bulbar blockade Aesthesiology 63: 688-690 and Hamilton RC, Gimbel HV. Regional anesthesia for 12000 cataract extraction and IOL Can J Anaesth.1988; 35:615-623.

18. Hansen EA, Mein CE, Mazzoli R (1990) Ocular anesthesia for cataract surgery: a direct sub-Tenon's approach. Ophthalmic Surg 21: 696-699.

19. Kallio H, Rosenberg PH (2005) Advances in ophthalmic regional anesthesia. Best Pract Res Clin Anaesthesiol 19: 215-227.

20. Kershner RM (1993) Topical anesthesia for small incision self-sealing cataract surgery. A prospective evaluation of the first 100 patients. $\mathrm{J}$ Cataract Refract Surg 19: 290-292.

21. Linebarger EJ, Hardten DR, Shah GK, Lindstrom RL (1999) Phacoemulsification and modern cataract surgery. Surv Ophthalmol 44: 123147.

22. Malik A, Fletcher EC, Chong V, Dasan J (2010) Local anesthesia for cataract surgery. J Cataract Refract Surg 36: 133-152.

23. Soliman MM, Macky TA, Samir MK (2004) Comparative clinical trial of topical anesthetic agents in cataract surgery: lidocaine $2 \%$ gel, bupivacaine $0.5 \%$ drops, and benoxinate $0.4 \%$ drops. J Cataract Refract Surg 30: 1716-1720.

24. Monestam E, Kunsik M (2000) dep of opth. Umea Uni .Sweden Cataract Prelimbal topical anesthesia was an effective and easy Refer Surg 26: 14031408.

25. Rocha G, Turner C (2007) Safety of cataract surgery under topical anesthesia with oral sedation without anesthetic monitoring. Can J Ophthalmol 42: 288294.

26. Said K, Hassan M, Qahtani FA (2003) A comparative study of topical versus peribulbar anesthesia in phacoemulsification and implantation of foldable intraocular lens in cataract surgery. IJOVS 2.

27. Tseng SH, Chen FK (1998) A randomized clinical trial of combined topical- 
intracameral anesthesia in cataract surgery. Ophthalmology 105: 2007-2011.

28. Vargas LG, Peng Q, Escobar-Gomez M, Schmidbauer JM, Apple DJ (2001) Overview of modern foldable intraocular lenses and clinically relevant anatomy and histology of the crystalline lens. Int Ophthalmol Clin 41: 1-15.

29. Yepez J, Cedeno de Yepez J \& Arevalo JF (1999) Topical anesthesia for phacoemulsification, intraocular lens implantation and posterior vitrectomy. J Cataract Refract Surg 25: 1161-1164.

30. Zehetmayer M, Radax U, Skorpik C, Menapace R, Schemper M, et al. (1996) Topical versus peribulbar anesthesia in clear corneal cataract surgery. $J$ Cataract Refract Surg 22: 480-484.

Copyright: (c) 2015 Vakharia D, et al. This is an open-access article distributed under the terms of the Creative Commons Attribution License, which permits unrestricted use, distribution, and reproduction in any medium, provided the original author and source are credited.

Citation: Vakharia D, Gokhale SK (2015) A Comparative Study of Topical Versus Peribulbar Anaesthesia in Phacoemulsification Cataract Surgery and 